\title{
LEGUME NITROGEN UTILISATION UNDER DROUGHT STRESS
}

\author{
V. Castañeda, E. Gil-Quintana, A. Echeverria and EM. González
}

\section{Summary}

Legumes, account for around $27 \%$ of the world's primary crop production and can be classified based on their use and traits into grain and forage legumes. Legumes can establish symbiosis with $\mathrm{N}$-fixing soil bacteria. As a result, a new organ is formed, the nodule, where the reduction of atmospheric $\mathrm{N}_{2}$ into ammonia is carried out catalyzed by the bacterial exclusive enzyme nitrogenase. The process, highly energy demanding, is known as symbiotic nitrogen fixation and provides all the $N$ needs of the plant, thus avoiding the use of $N$ fertilizers in the context of sustainable agriculture. However, legume crops are often grown under non-fixing conditions since legume nodulation is suppressed by high levels of soil nitrogen occurring in chemically fertilized agroenvironment. In addition, legumes are very sensitive to environmental stresses, being drought one of the significant constraints affecting crop production. Due to their agricultural and economic importance, scientists have carried out basic and applied research on legumes to 
better understand responses to abiotic stresses and to furher comprehend plant-microbe interactions. An integrated view of nitrogen utilization under drought stress will be presented with particular focus on legume crops.

\section{Drought stress}

Climate change is multi-faceted and includes changing concentrations of greenhouse gases in the atmosphere (like $\mathrm{CO}_{2}$ ), rising temperatures, changes in precipitation patterns, and increasing frequency of extreme weather events (Gray and Brady, 2016). Thus, Earth's climate is drastically changing leading to more intense and extended drought situations. Indeed, the area affected by drought has increased substantially since the middle $20^{\text {th }}$ century (Dai, 2011), and the frequency of droughts is predicted to increase in regions that are already dry by the end of the $21^{\text {st }}$ century. Drought observatories have estimated that around $40 \%$ of the land area is affected by drought and has an expectative in expansion due to the global climate change (Trenberth et al., 2013). It has been estimated that two-thirds of the potential yield of major crops are usually lost due to adverse growing 
environments (Bajaj et al., 1999; Daryanto et al., 2016). Abiotic stresses, above all water deficit, are the most important factors limiting crop productivity, with a growing importance due to the increase in climate alterations such as reduced rainfall (Lesk et al., 2016). Indeed, most climate change studies predict an increase in arid areas worldwide (Shu et al., 2007), aggravated by the rapidly increasing world population, which puts pressure on food and water demands (Somerville and Briscoe, 2001). This problem not only arises from the limiting nature of water supplies, but also from the increased need for food production, which leads to an improper management of agricultural lands. For example, most crops are cultivated in lands and regions to which they are not optimally adapted, yielding up to $22 \%$ of their genetic potential due to improper climatic and soil conditions (Boyer, 1982). Therefore, the understanding of plant drought stress tolerance has become an urgent matter, since it can allow us a better management and to minimize its harmful effects on crops.

Drought is defined as "the decrease in water inputs into an agro/ecosystem over time that is sufficient to result in soil water 
deficit (i.e., decrease in the available soil water)" (Gilbert and Medina, 2016). Therefore, drought is a condition of climatic dryness severe enough to reduce soil moisture and water below the minimums necessary for sustaining plant, animal and human life (Perez and Thompson, 1996). This stress interferes with the optimal plant growth, physiology, and reproduction, ultimately causing a significant reduction in plant productivity (Farooq et al., 2009). Water deficit can be defined as any water content of a tissue or cell below the highest water content exhibited in the most hydrated state. Although the terms "drought stress" and "water-deficit stress" are usually employed indistinctively, water does not only become limiting for plant communities as a result of inadequate rainfall but also due to other environmental conditions like excessive salinity in the soil solution or as a consequence of freezing temperatures. In this work, the term drought stress will be used referring to periods where water is withheld from the plant.

\section{Drought is a major threat to legumes crops}


Grain and forage legumes are grown on around $15 \%$ of the arable surface of the Earth, being the second most important crop after cereals attending to world first crop production (FAOSTAT; Graham and Vance, 2003). The economic relevance of legume crops is related to both their importance as a protein source for animal feed and human nutrition and their use as raw material in the industry (Edgerton et al., 2008). Common bean, soybean, chickpea, pea and faba bean are some of the most widely cultivated grain legumes, while cowpea, pigeon pea, lentils and grass pea play an essential nutritional role in low-income regions of the world. Regarding forage legumes, plants in the Medicago, Trifolium, and Lotus genera are probably the most extended legumes for livestock production. Furthermore, the ability of legume plants to carry out nitrogen fixation in symbiosis with soil rhizobium bacteria provides an environmental-friendly source of reduced nitrogen in the biosphere, being an essential element in sustainable agriculture worldwide.

Despite the numerous advantages of the cultivation of legumes, one of the factors that limit their wider cultivation is the reduction of legume crop yields due to abiotic stress conditions, particularly drought. 
Three are the main factors contributing to this limitation of productivity: i) in intensive crop-based agricultural systems worldwide, legumes are commonly grown under rain-fed conditions. This is the case in the Mediterranean area (Jacobsen et al. 2012), USA, Brazil and Argentina, the three countries responsible for $87 \%$ world's soybean production (FAOSTAT, 2013), or Asia (Kumar and Abbo, 2001); ii) legumes are often grown in rotation after cereal harvest towards the end of the growing season when environmental conditions are more limiting for plant growth; and iii) improvement in legume crop yields has not kept pace with those of cereals, for which higher yielding modern varieties have been developed (Jeuffroy and Ney, 1997). The limitations described above, along with the predictions of an increasing world food demand (Postel, 2000) and the rise in temperature at the global level, are driving forces for the investigation of legume responses to drought towards the ultimate development of new varieties with improved water use efficiency and drought tolerance.

\section{Regulation of nitrogen fixation under drought}


Legumes can establish symbiosis with $\mathrm{N}$-fixing soil bacteria. As a result, a new organ is formed, the nodule, where the reduction of atmospheric $\mathrm{N}_{2}$ into ammonia is carried out catalyzed by the bacterial exclusive enzyme nitrogenase. This process is known as symbiotic nitrogen fixation (SNF) and may provide all the $N$ needs of the plant, avoiding the use of $\mathrm{N}$ fertilizers in the context of sustainable agriculture. The effects of drought on SNF occur at different steps of the symbiotic interaction: infection, nodule development, and nodule functioning. Under drought, both, the formation of new root hairs and the elongation of previously differentiated root hairs are limited and, as a consequence, the development of new plant-bacteria interactions and infection threads is greatly reduced (Worrall and Roughley, 1976). Moreover, SNF is one of the physiological processes to first show stress responses in nodulated legumes, a decline that cannot be explained by the relatively slow decline in photosynthetic rates (Durand et al., 1987).

Although several hypotheses have been proposed to explain the decline in SNF during drought, the origin of the inhibitory signals, the 
molecular mechanisms involved and the interaction among the factors responsible for the inhibition of SNF are not yet fully understood. It has been postulated that drought stress provokes an increase in nodular oxygen diffusion resistance and thus, a decline in the oxygen level for bacteroid respiration (Durand et al., 1987). However, the increase of oxygen concentration in the rhizosphere of drought-stressed nodules does not fully restore NF rates, suggesting that other factors are also involved (Del Castillo et al., 1994; Del Castillo and Layzell, 1995).

The availability of carbon in nodules as supply for bacteroid respiration and nitrogenase activity is the second regulatory mechanism suggested (Figure 1). The main carbon source transported from the aerial part is sucrose, which is hydrolyzed in nodules by sucrose synthase (SuSy). The essential role of SuSy for NF has been shown for pea (Gordon et al., 1999) and the model legume M. truncatula (Baier et al., 2007). Indeed, Gordon et al showed a correlation between SuSy activity decline and NF inhibition in stressed soybean nodules (Gordon et al., 1997). Moreover, SuSy has been shown to be the first enzyme to decline under drought stress in soybean (Gonzalez et al., 1995), pea 
(Gonzalez et al., 1998; Galvez et al., 2005) and common bean (Ramos et al., 1999), leading to the accumulation of sucrose and the depletion of organic acids, principally malate, in nodules. However, the SuSy mediated NF inhibition seems not to take place in forage legumes such as M. sativa (Naya et al., 2007) and M. truncatula (Larrainzar et al., 2009). In these studies, significant declines in the SuSy activity were found only after the inhibition of NF and concomitant to malate accumulation, suggesting that carbon availability is not the limiting factor for the inhibition of NF in these plants. Moreover, in a recent metabolomic approach, the limitation of respiratory carbon substrates was demonstrated not to be the cause of NF inhibition in droughtstressed M. truncatula nodules (Larrainzar et al., 2009).

The third suggested factor implies a $\mathrm{N}$-feedback mechanism involving the $\mathrm{N}$-status of the plant. This theory has received much attention in ureide-exporter tropical legumes, mostly due to studies conducted in soybean. Legumes can be classified into amide- or ureideexporters according to the compounds used for the transport of fixed $N$ compounds. In general, amide-exporter legumes, such as $M$. 
truncatula, contain indeterminate type nodules and are originated from temperate regions. These plants transport fixed nitrogen in the form of amides, mainly asparagine and glutamine. On the other hand, ureideexporter legumes, such as soybean, are mostly tropical legumes with determinate type nodules and transport mainly allantoin and allantoic acid. However, exceptions to this general pattern can be found. For instance, the temperate legume Lotus spp., with the determinate type of nodules, exports amides rather than ureides (Sprent, 2001). Several $\mathrm{N}$ compounds have been suggested as inhibitory signal molecules, such are the cases of ureides (Serraj et al., 1999; Vadez and Sinclair, 2000), glutamine (Neo and Layzell, 1997), asparagine (Bacanamwo and Harper, 1997; Vadez et al., 2000) and aspartate (King and Purcell, 2005). The restriction on the export of $N$ compounds, with their subsequent accumulation in the nodules in water deficit conditions has also been postulated (Pate et al., 1969; Walsh, 1989a,b). Serraj et al. (2001a) refined the model by proposing two possible origins for the feedback inhibition: a direct feedback within the nodules and an indirect feedback due to $\mathrm{N}$ compound signals coming from the aerial part. A more 
recent study showed that ureides were accumulated in soybean nodules and not in leaves, suggesting a local regulation of NF (Ladrera et al., 2007). Recent works using Split-Root-System-based approaches confirm the operation of local regulatory mechanisms controlling SNF in pea (Marino et al. 2007), M. truncatula (Gil-Quintana et al. 2013a), and soybean (Gil-Quintana et al. 2013b) under water deficit conditions. The concomitant reduction in nitrogenase activity, malate content and Susy activity in the nodules of the unwatered split-root section supports the existence of a local carbon-based regulation of SNF in pea (Marino et al. 2007). In addition, the general variations in amino acid and ureide content in leaves, roots and nodules (Gil-Quintana et al. $2013 a, b)$ challenged the widely accepted $\mathrm{N}$-based systemic regulation hypothesis (King and Purcell 2005; Sulieman et al. 2010), reinforcing the direct feedback inhibition in the nodules hypothesis.

\section{Drought stress effect on the root system}

Although legume crops may lend to a sustainable use of nitrogen fertilizers, the nitrogen-fixing process is mostly suppressed in nitrogen 
fertilized agro-environments (Murray et al., 2017). Under these conditions, legume response to drought would be similar to that of other cultivated crops, even though attention should be paid to specific features of legume plants (Figure 1). In herbaceous crops, most of the nitrate is reduced predominantly in the shoots via the reducing equivalents derived from photosynthesis (Scheurwater et al., 2002; Hachiya et al., 2016). Leaf nitrate reduction declines rapidly in response to drought in important crops such as maize (Foyer et al., 1998) or wheat (Fresneau et al., 2007) which correlate with the decline of the photosynthetic process. However, temperate legumes assimilate nitrate chiefly in the roots when growing under low $N$ supply, while shoot nitrate assimilation becomes increasingly important as the nitrate concentration increases (Andrews, 1986). Conversely, tropical legumes exhibit constant ratios of the shoot to root nitrate assimilation where this ratio is specific for each species (Andrews, 1986). These features have not been tested for the current model plants for temperate and tropical legumes, Medicago and Lotus, respectively. Unlike nitrate, ammonium is chiefly assimilated in the roots by the coordinated 
activities of GS and GOGAT (Funayama et al., 2013; Guan et al., 2015; Trepp et al., 1999a, b). In the context of legume plants, ammonium nutrition would closely mimic the symbiotic $\mathrm{N}$-fixing legumes since bacteroids assimilate very little of the fixed ammonia, which is mainly exported to the host plant (Brown and Dilworth, 1975; Vance et al., 1994). In this context, legumes have been shown to be relatively tolerant to ammonium nutrition (Dominguez-Valdivia et al., 2008; Ariz et al., 2010).

Roots are the first organs that sense water deficit in soils and interact directly with edaphic water, and therefore drought responses of this organ are highly important. Several studies try to dissect the molecular response of roots of different legumes to drought stress (Micheletto et al., 2007; Zhang et al., 2014). In this context, the primary nitrogen assimilation pathway does not seem to be severely affected under drought stress conditions. This response seems coherent since drought affects cell growth and protein synthesis even at a very moderate level (Hsiao, 1973) and hence nitrogen demand is expected to be reduced. With regards to carbon economy, Muller et al. 
(2011) highlighted a lack of correlation between carbon availability and sink organ growth under water-deficit stress.

Regarding nitrogen metabolism, drought provokes an overall accumulation of amino acids in roots of nodulated (Gil-Quintana et al., 2013) and non-nodulated plants (Frechilla et al., 2000) thereby dismissing a possible nitrogen starvation in drought-stressed plants. In addition, changes in protein synthesis and degradation may strongly affect the pool of free amino acids. Taking as reference the amino acid composition of the Arabidopsis proteome, Hildebrandt et al. (2015) estimated that the pool size of the protein-bound amino acids varied less than ten folds. Therefore, inhibition of protein synthesis (Lyon et al., 2016) or enhancement of proteolytic activities (Kohli et al., 2012) could influence the overall accumulation of the free amino acid pools in drought-stressed tissues. Lyon et al. (2016) highlight the importance of protein turnover dynamics in drought recovery processes. On the other hand, pool sizes of the free amino acids, which are around 100-1000fold smaller than the corresponding pools of protein-bound amino acids, are highly diverse (Gil-quintana et al., 2013; Watanabe et al., 2013). This 
reflect the various functional roles of these compounds and their interaction with the synthesis of other relevant compounds such as nucleotides or hormones. Amino acid synthetic pathways mainly consume intermediates from glycolysis, the pentose phosphate pathway, and the citric acid cycle and the involved enzymes are mostly located in the plastid with some of them addressed to the cytosol (reviewed in Pratelli and Pilot, 2014). In general, the primary products of nitrogen assimilation, Glu, Gln, Asp, and Asn, constitute the larger pools in plants (Coruzzi, 2003) although they are not much induced during stress, and accordingly, primary nitrogen assimilation enzyme activities rarely increase in response to drought stress (Larrainzar et al., 2009). Conversely, other less abundant amino acids under control conditions such as Pro (Jacoby et al., 2011), branched chain amino acids (Joshi et al., 2010), Lys and Thr (Obata and Fernie, 2012) and His and Trp (Larrainzar et al., 2009) respond individually to drought. Accordingly, the expression of different enzymes involved in the synthesis of some amino acids is eventually affected (Pratelli and Pilot, 2014). Unlike the amino acid synthesis, catabolism is mainly addressed to the 
mitochondria or the cytosol (Hildebrandt et al., 2015). The involvement of mitochondria favors the nitrogen and carbon recycling during the senescence processes occurring under drought stress since mitochondria functionality remains longer than that of other organelles (Avila-Ospina et al., 2014). Araújo et al. (2011) pointed to protein degradation and amino acid catabolism as an alternative carbon source for respiratory processes in stressed plants. Research on amino acid metabolism needs to be expanded for a better understanding on intracellular compartmentalization (Mintz-Oron et al., 2012) dealing not only to photosynthetic tissue but also to those exhibiting a heterotrophic metabolism such as roots.

Furthermore, an active long-distance transport of the amino acids between root and shoot occurs involving both, the phloem and the xylem vascular tissues (Jeschke and Hartung, 2000). In legumes, amino acids are mainly transported via the xylem (Atckings et al., 1983) but concomitantly some amino acids may be transferred to the phloem to supply nitrogen directly to the sink (Zhang et al., 2010; Tegether, 2014). Recent studies have shown that transport of amino acids between shoot 
and roots determine nitrogen uptake and metabolism (Miller at al., 2008; Santiago and Tegeder, 2016). However, the role of long-distant transport of amino acids needs to be studied further to better understand the changes in the source-sink interactions occurring under drought. The amino acid exchange requires continuous inward and outward transport across membranes, and numerous genes encoding amino acid transporters have been described (Jack et al., 2000). The induction of proline transporters has been reported in Arabidopsis and rice exposed to drought and salt stress (Rentsch et al., 1996; Zhao et al., 2012). In addition, the expression level of different amino acid transporters showed a differential response to drought among shoots and roots in wheat, suggesting that they may play a role in the amino acid exchange among aerial and underground tissues (Wang et al., 2017).

\section{Future prospects}

Legume crops can fix atmospheric nitrogen through their symbiotic association with $\mathrm{N}$-fixing bacteria or by using chemical fertilizers. In this latter case, the legume root exhibits particular features such as a 
higher tolerance to ammonium and the ability to carry out nitrate reduction to a greater extent than other non-legume crops. Regarding nodulated plants, the nitrogen fixation process has been shown to be rapidly inhibited under moderate drought stress conditions. For those nitrogen fertilized legumes, few studies have been carried out at root level, although it is widely known that nitrate reductase activity is severely affected in leaves. However, although the different nitrogen assimilation processes seem to be impaired in legumes, the general accumulation of nitrogen compounds occurring in the different tissues dismiss any possible nitrogen scarcity playing a pivotal role in the legume response to drought. Indeed, cell growth is one of the processes firstly affected by water deficit stress at a moderate level and hence nitrogen demand is presumed to be lower under drought stress. Further knowledge on long distant transport of nitrogen compounds and amino acid metabolism compartmentalization may contribute to improving legume nitrogen utilization under moderate water stress conditions. 



\section{References}

Andrews M. 1986. Nitrate and reduced- $N$ concentrations in the xylem sap of Stellaria media, Xanthium strumarium and six legume species. Plant, Cell and Environment 9: 605-608.

Araujo WL, Tohge T, Ishizaki K, Leaver CJ, Fernie AR. 2011. Protein degradation - an alternative respiratory substrate for stressed plants. Trends in Plant Science, 16: 489-498.

Ariz I, Esteban R, García-Plazaola JI, Becerril JM, Aparicio-Tejo PM, Moran JF. 2010. High irradiance induces photoprotective mechanisms and a positive effect on $\mathrm{NH}^{+}{ }_{4}$ stress in Pisum sativum L. Journal of Plant Physiology 167: 1038-1045.

Atkins CA, Pate JS, Peoples MB, Joy KW. 1983. Amino acid transport and metabolism in relation to the nitrogen economy of a legume leaf. Plant Physiology 71: 841-848

Avila-Ospina L, Moison M, Yoshimoto K, Masclaux-Daubresse C. 2014. Autophagy, plant senescence, and nutrient recycling. Journal of Experimental Botany 65: 3799-3811.

Bacanamwo M, Harper JE. 1997. The feedback mechanism of nitrate inhibition of nitrogenase activity in soybean may involve asparagine and/or products of its metabolism. Physiologia Plantarum 100: 371-377.

Baier MC, Barsch A, Kuester H, Hohnjec N. 2007. Antisense repression of the Medicago truncatula nodule-enhanced sucrose synthase leads to a handicapped nitrogen fixation mirrored by specific alterations in the symbiotic transcriptome and metabolome. Plant Physiology 145: 1600-1618.

Bajaj S, Targolli J, Liu LF, David Ho TH, Wu R. 1999. Transgenic approaches to increase dehydration-stress tolerance in plants. Molecular Breeding 5: 493-503.

Boyer JS. 1982. Plant Productivity and Environment. Science. 218: 443-448.

Brown CM, Dilworth MJ. 1975. Ammonia assimilation by rhizobium cultures and bacteroids. Journal of General Microbiology 86: 39-48.

Coruzzi GM. 2003. Primary N-assimilation into amino acids in Arabidopsis. Arabidopsis Book 2:e0010.

Dai A. 2011. Drought under global warming: a review. Wiley Interdisciplinary Reviews: Climate Change 2: 45-65.

Daryanto S, Wang L, Jacinthe PA, Yu X, Luo L, Cui K. 2016. Global synthesis of drought effects on maize and wheat production. PLoS One 11, e0156362. 
Del Castillo LD, Layzell DB. 1995. Drought stress, permeability to $\mathrm{O}_{2}$ diffusion, and the respiratory kinetics of soybean root-nodules. Plant Physiology 107: 1187-1194.

Del Castillo LD, Hunt S, Layzell DB. 1994. The role of oxygen in the regulation of nitrogenase activity in drought-stressed soybean nodules. Plant Physiology 106: 949-955.

Domínguez-Valdivia MD, Aparicio-Tejo PM, Lamsfus $C, C r u z ~ C$, Martins-Loução MA, Moran JF. 2008. Nitrogen nutrition and antioxidant metabolism in ammonium-tolerant and -sensitive plants. Physiologia Plantarum 132: 359369.

Durand JL, Sheehy JE, Minchin FR. 1987. Nitrogenase activity, photosynthesis and nodule water potential in soybean plants experiencing water-deprivation. Journal of Experimental Botany 38: 311-321.

Edgerton SA, MacCracken MC, Jacobson MZ, Ayala A, Whitman CE, Trexler MC. 2008. Prospects for Future Climate Change and the Reasons for Early Action. Journal of the Air and Waste Management Association 58: 13861400

Faroog M, Wahid A, Kobayashi N, Fujita D, Basra SMA. 2009. Plant Drought Stress: Effects, Mechanisms and Management, In: Sustainable Agriculture. Springer Netherlands, Dordrecht, pp. 153-188.

Foyer CH, Valadier M-H, Migge A, Becker TW. 1998. Drought-induced effects on nitrate reductase activity and $m R N A$ and on the coordination of Nitrogen and carbon metabolism in maize leaves. Plant Physiology 117: 283-292.

Frechilla S, González EM, Royuela M, Minchin FR, Aparicio-Tejo PM, ArreseIgor C. 2000. Source of nitrogen nutrition (nitrogen fixation or nitrate assimilation) is a major factor involved in pea response to moderate water stress. Journal of Plant Physiology 157: 609-617.

Fresneau C, Ghashghaie J, Cornic G. 2007. Drought effect on nitrate reductase and sucrose-phosphate synthase activities in wheat (Triticum durum L.): role of leaf internal $\mathrm{CO}_{2}$. Journal of Experimental Botany, 58: 2983-2992.

Funayama K, Kojima S, Tabuchi-Kobayashi M, Sawa Y, Nakayama Y, Hayakawa T, Yamaya T. 2013. Cytosolic glutamine synthetase1;2 is responsible for the primary assimilation of ammonium in rice roots. Plant and Cell Physiology 54: 934-943.

Galvez L, Gonzalez EM, Arrese-Igor C. 2005. Evidence for carbon flux shortage and strong carbon/nitrogen interactions in pea nodules at early stages of water stress. Journal of Experimental Botany 56: 2551-2561. 
Gilbert ME, Medina V. 2016. Drought adaptation mechanisms should guide experimental design. Trends in Plant Science 21: 639-647.

Gil-Quintana E, Larrainzar E, Arrese-Igor C, González EM. 2013. Is Nfeedback involved in the inhibition of nitrogen fixation in drought-stressed Medicago truncatula? Journal Experimental Botany 64: 281-292.

Gonzalez EM, Aparicio-Tejo PM, Gordon AJ, Minchin FR, Royuela M, ArreseIgor C. 1998. Water-deficit effects on carbon and nitrogen metabolism of pea nodules. Journal of Experimental Botany 49: 1705-1714.

Gonzalez EM, Gordon AJ, James C, Arrese-Igor C. 1995. The role of sucrose synthase in the response of soybean nodules to drought. Journal of Experimental Botany 46: 1515-1523.

Gordon AJ, Minchin FR, James CL, Komina O. 1999. Sucrose synthase in legume nodules is essential for nitrogen fixation. Plant Physiology 120: 867-877.

Gordon AJ, Minchin FR, Skot L, James CL. 1997. Stress-induced declines in soybean $\mathrm{N}_{2}$ fixation are related to nodule sucrose synthase activity. Plant Physiology 114: 937-946.

Graham PH, Vance CP. 2003. Legumes: importance and constraints to greater use. Plant Physiology 131: 872-877.

Gray SB, Brady SM. 2016. Plant developmental responses to climate change. Developmental Biology 419: 64-77.

Guan M, Møller IS, Schjoerring JK. 2015. Two cytosolic glutamine synthetase isoforms play specific roles for seed germination and seed yield structure in Arabidopsis. Journal of Experimental Botany 66: 203-212.

Hachiya T, Ueda N, Kitagawa M, Hanke G, Suzuki A, Hase T, Sakakibara $H$. 2016. Arabidopsis root-type ferredoxin:NADP(H) oxidoreductase 2 is involved in detoxification of nitrite in roots. Plant and Cell Physiology 57: 2440-2450.

Hildebrandt TM, Nunes Nesi A, Araujo WL, Braun H-P. 2015. Amino Acid Catabolism in Plants. Molecular Plant 8, 1563-1579.

Hsiao TC. 1973. Plant responses to water stress. Annual Review of Plant Physiology and Plant Molecular Biology 24: 519-570.

Jack DL, Paulsen IT, Saier MH. 2000. The amino acid/polyamine/ organocation (APC) superfamily of transporters specific for amino acids, polyamines and organocations. Microbiology 146: 1797-1814.

Jacobsen SE, Jensen CR, Liu F. 2012. Improving crop production in the arid Mediterranean climate. Field Crops Research 128: 34-47.

Jacoby RP, Taylor NL, Millar AH. 2011. The role of mitochondrial respiration in salinity tolerance. Trends in Plant Science 16: 614-623. 
Jeschke WD, Hartung W. 2000. Root-shoot interactions in mineral nutrition. Plant and Soil 226: 57-69.

Jeuffroy MH, Ney B. 1997. Crop physiology and productivity. Field Crop Research 53: 3-16.

Joshi V, Joung JG, Fei Z, Jander G. 2010. Interdependence of threonine, methionine and isoleucine metabolism in plants: accumulation and transcriptional regulation under abiotic stress. Amino Acids 39: 933-947.

King CA, Purcell LC. 2005. Inhibition of $\mathrm{N}_{2}$ fixation in soybean is associated with elevated ureides and amino acids. Plant Physiology 137: 1389-1396.

Kohli A, Narciso JO, Miro B, Raorane M. 2012. Root proteases: reinforced links between nitrogen uptake and mobilization and drought tolerance. Physiologia Plantarum 145: 165-179.

Kumar J, Abbo S. 2001. Genetics of flowering time in chickpea and its bearing on productivity in semiarid environments. Advanced Agronomy 72: 107-138.

Ladrera R, Marino D, Larrainzar E, Gonzalez EM, Arrese-Igor C. 2007. Reduced carbon availability to bacteroids and elevated ureides in nodules, but not in shoots, are involved in the nitrogen fixation response to early drought in soybean. Plant Physiology 145: 539-546.

Larrainzar E, Wienkoop S, Scherling C, Kempa S, Ladrera R, Arrese-Igor C, Weckwerth W, Gonzalez EM. 2009. Carbon metabolism and bacteroid functioning are involved in the regulation of nitrogen fixation in Medicago truncatula under drought and recovery. Molecular Plant-Microbe Interactions 22: 1565-1576.

Lesk C, Rowhani P, Ramankutty N. 2016. Influence of extreme weather disasters on global crop production. Nature 529: 84-87.

Lyon D, Castillejo MA, Mehmeti-Tershani V, Staudinger $C$, Kleemaier $C$, Wienkoop S. 2016. Drought and recovery: Independently regulated processes highlighting the importance of protein turnover dynamics and translational regulation in Medicago truncatula. Molecular \& Cellular Proteomics 15.6

Marino D, Frendo P, Ladrera R, Zabalza A, Puppo A, Arrese-Igor C, Gonzalez EM. 2007. Nitrogen fixation control under drought stress. Localized or systemic? Plant Physiology 143: 1968-1974.

Micheletto S, Rodriguez-Uribe L, Hernandez R, Richins RD, Curry J, O'Connell MA. 2007. Comparative transcript profiling in roots of Phaseolus acutifolius and $P$. vulgaris under water deficit stress. Plant Science 173: 510-520.

Miller AJ, Shen $Q, X u G$. 2008. Freeways in the plant: transporters for $N, P$ and $S$ and their regulation. Current Opinion in Plant Biology 12: 284-290. 
Mintz-Oron S, Meir S, Malitsky S, Ruppin E, Aharoni A, Shlomi T. 2012. Reconstruction of Arabidopsis metabolic network models accounting for subcellular compartmentalization and tissue-specificity. Proceedings of the National Academy of Sciences, USA 109, 339-344.

Muller B, Pantin F, Genard M, Turc O, Freixes S, Piques M, Gibon Y. 2011. Water deficits uncouple growth from photosynthesis, increase $C$ content, and modify the relationships between $C$ and growth in sink organs. Journal of Experimental Botany 62: 1715-1729.

Murray JD, Cheng-Wu L, Chen Y, Miller AJ. 2017. Nitrogen sensing in legumes. Journal of Experimental Botany 68: 1919-1926.

Naya L, Ladrera R, Ramos J, Gonzalez EM, Arrese-Igor C, Minchin FR, Becana M. 2007. The response of carbon metabolism and antioxidant defenses of alfalfa nodules to drought stress and to the subsequent recovery of plants. Plant Physiology 144: 1104-1114.

$\mathrm{Neo} H \mathrm{H}$, Layzell DB. 1997. Phloem glutamine and the regulation of $\mathrm{O}_{2}$ diffusion in legume nodules. Plant Physiology 113: 259-267.

Obata T, Fernie AR. 2012. The use of metabolomics to dissect plant responses to abiotic stresses. Cell Molecular Life Science 69: 3225-3243.

Pate JS, Gunning BES, Briarty LG. 1969. Ultrastructure and functioning of transport system of leguminous root nodule. Planta 85: 11-34.

Perez E, Thompson P. 1996. Natural hazards: causes and effects. Lesson 7 Drought. Prehospital and Disaster Medicine 11:71-77.

Postel SL. 2000. Water and world population growth. American Water Works Association Journal 92: 131-138.

Pratelli R, Pilot G. 2014. Regulation of amino acid metabolic enzymes and transporters in plants. Journal of Experimental Botany 65: 5535-5556.

Ramos MLG, Gordon AJ, Minchin FR, Sprent JI, Parsons R. 1999. Effect of water stress on nodule physiology and biochemistry of a drought tolerant cultivar of common bean (Phaseolus vulgaris L.). Annals of Botany 83: 57-63.

Rentsch D, Hirner B, Schmelzer E, Frommer W. B. 1996. Salt stress-induced proline transporters and salt stress-repressed broad specificity amino acid permeases identified by suppression of a yeast amino acid permeasetargeting mutant. Plant Cell 8: 1437-1446.

Santiago JP, Tegeder M. 2016. Connecting source with sink: the role of Arabidopsis AAP8 in phloem loading of amino acids. Plant Physiology 171: 508521. 
Scheurwater I, Koren M, Lambers H, Atkin OK. 2002. The contribution of roots and shoots to whole plant nitrate reduction in fast- and slowgrowing grass species. Journal of Experimental Botany 53: 1635-1642.

Serraj R, Vadez V, Sinclair TR. 2001. Feedback regulation of symbiotic $\mathrm{N}_{2}$ fixation under drought stress. Agronomie 21: 621-626.

Serraj R, Vadez V, Denison RF, Sinclair TR. 1999. Involvement of ureides in nitrogen fixation inhibition in soybean. Plant Physiology 119: 289-296.

Shu FH, Shang H, Glassgold AE, Lee T, Baker J, Bizzarro M, Wittig N, Connelly $\mathrm{J}$, Haack H. 2007. Model projections of an imminent transition to a more arid climate. Science 316: 1181-1475.

Somerville C, Briscoe J. 2001. Genetic Engineering and Water. Science. 292: 2217.

Sprent JI. 2001. Nodulation in legumes. Royal Botanic Gardens, Kew.

Sulieman S, Fischinger SA, Gresshoff PM, Schulze J. 2010. Asparagine as a major factor in the $\mathrm{N}$-feedback regulation of $\mathrm{N}_{2}$ fixation in Medicago truncatula. Physiologia Plantarum 140: 21-31.

Tegeder M. 2014. Transporters involved in source to sink partitioning of amino acids and ureides: opportunities for crop improvement. Journal of Experimental Botany 65: 1865-1878.

Trenberth KE, Dai A, van der Schrier G, Jones PD, Barichivich J, Briffa KR, Sheffield J. 2013. Global warming and changes in drought. Nature Climate Change 4: 17-22.

Trepp GB, Plank DW, Gantt JS, Vance CP. 1999a. NADH-glutamate synthase in alfalfa root nodules. Immunocytochemical localization. Plant Physiology 119: 829-837.

Trepp GB, van de Mortel M, Yoshioka H, Miller SS, Samac DA, Gantt JS, Vance CP. 1999b. NADH-glutamate synthase in alfalfa root nodules. Genetic regulation and cellular expression. Plant Physiology 119: 817-828.

Vadez V, Sinclair TR. 2000. Ureide degradation pathways in intact soybean leaves. Journal of Experimental Botany 51: 1459-1465.

Vadez V, Sinclair T, Serraj R. 2000. Asparagine and ureide accumulation in nodules and shoots as feedback inhibitors of $\mathrm{N}_{2}$ fixation in soybean. Physiologia Plantarum 110: 215-223.

Vance CP, Gregerson RG, Robinson DL, Miller SS, Gantt JS. 1994. Primary assimilation of nitrogen in alfalfa nodules - Molecular features of the enzymes involved. Plant Science 101: 51-64. 
Walsh KB, Canny MJ, Layzell DB. 1989a. Vascular transport and soybean nodule function .2. A role for phloem supply in product export. Plant, Cell and Environment 12: 713-723.

Walsh KB, McCully ME, Canny MJ. 1989b. Vascular transport and soybean nodule function - Nodule xylem is a blind alley, not a throughway. Plant Cell and Environment 12: 395-405.

Wan Y, King R, Mitchell RAC, Hassani-Pak K, Hawkesford MJ. 2017. Spatiotemporal expression patterns of wheat amino acid transporters reveal their putative roles in nitrogen transport and responses to abiotic stress. Scientific Reports 7: 5461

Watanabe M, Balazadeh S, Tohge T, Erban A, Giavalisco P, Kopka J, MuellerRoeber B, Fernie AR, Hoefgen R. 2013. Comprehensive dissection of spatiotemporal metabolic shifts in primary, secondary, and lipid metabolism during developmental senescence in Arabidopsis. Plant Physiology 162: 12901310.

Worrall VS, Roughley RJ. 1976. Effect of moisture stress on infection of Trifolium Subterraneum $L$. by RhizobiumTrifolii Dang. Journal of Experimental Botany 27: 1233-1241.

Zhang JY, Cruz DE, Carvalho MH, Torres-Jerez I, Kang Y, Allen SN, Huhman $D$, Tang Y, Murray J, Sumner LW, Udvardi MK. 2014. Global reprogramming of transcription and metabolism in Medicago truncatula during progressive drought and after rewatering. Plant, Cell and Environment 37: 2553-2576.

Zhang L, Tan Q, Lee R, Trethewy A, Lee YH, Tegeder M. 2010. Altered xylemphloem transfer of amino acids affects metabolism and leads to increased seed yield and oil content in Arabidopsis. Plant Cell 22: 3603-3620.

Zhao H, Ma H, Yu L, Wang X, Zhao J. 2012. Genome-wide survey and expression analysis of amino acid transporter gene family in rice (Oryza sativa L.). PLoS One. 7, e 49210 . 


\section{Legend to Figures}

Figure 1. A) Split-root system set up as a tool to study the local or systemic nature of plant signaling processes. B) Schematic representation of the main physiological and metabolic processes affected by drought at shoot, root and nodule level. AAT, aspartate aminotransferase; AS, asparagine synthase; $G S$, glutamine synthetase; GOGAT, glutamate synthase; NR, nitrate reductase; NiR, nitrite reductase; SNF, symbiotic nitrogen fixation; SuSy, sucrose synthase; TCA, tricarboxylic acid cycle. 


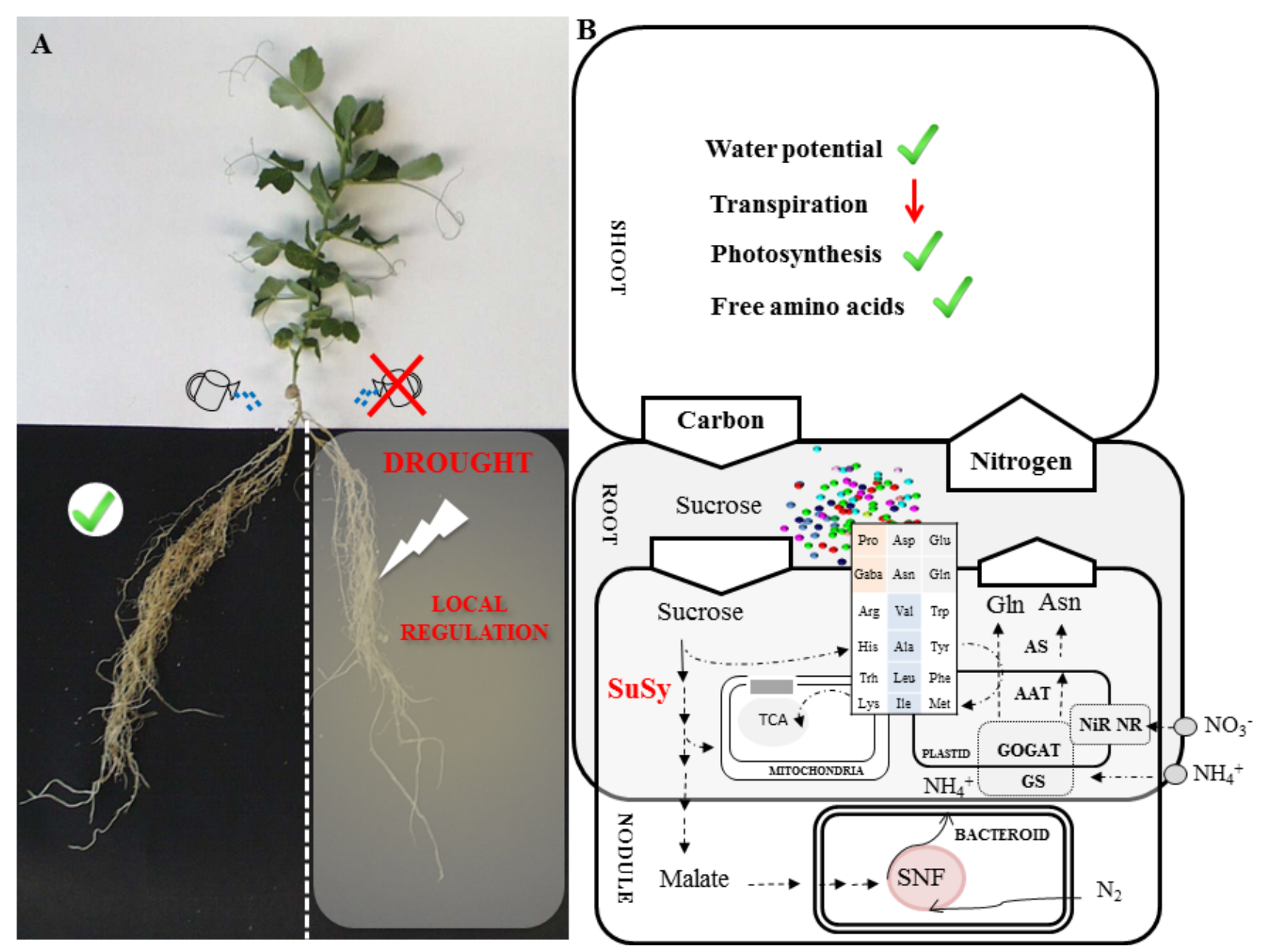

